\title{
Geothermal sources and utilization practice in six countries along the southern part of the Pannonian basin
}

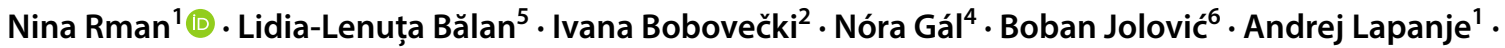 \\ Tamara Marković ${ }^{3}$ - Dejan Milenić ${ }^{7} \cdot$ Ferid Skopljak $^{8}$ · Ágnes Rotár-Szalkai ${ }^{4} \cdot$ Natalija Samardžić $^{8} \cdot$ Teodóra Szőcs $^{4}$. \\ Dragana Šolaja $^{9} \cdot$ Nenad Toholj $^{6} \cdot$ Anca-Marina Vijdea $^{5} \cdot$ Ana Vranješ $^{7}$
}

Received: 19 July 2019 / Accepted: 27 November 2019 / Published online: 9 December 2019

(c) The Author(s) 2019

\begin{abstract}
Data on thermal water sources with outflow temperature of $30{ }^{\circ} \mathrm{C}$ and above were analyzed from the N-ern parts of Bosnia and Herzegovina, Serbia and Croatia, S-ern parts of Hungary, W-ern parts of Romania, and NE-ern parts of Slovenia, altogether from an area of $99,347 \mathrm{~km}^{2}$. The overview identified 771 geothermal sources; only 7 were thermal springs. The average well depth is about $1.2 \mathrm{~km}$. About $13 \%$ of wells are younger than 10 years, additional $17 \%$ below 30 years; while $26 \%$ are older than 50 years. Average thermal water outflow temperature is $54{ }^{\circ} \mathrm{C}$ being the highest, $170{ }^{\circ} \mathrm{C}$, in Croatia. Most thermal water is produced from basin fill sediments-Lower and Upper Pannonian (Mio-Pliocene) loose sandstones which are tapped by $86 \%$ of wells. The rest appertains to basement rocks-fissured, fractured and karstified Paleozoic, Mesozoic and Middle Miocene metamorphic, carbonate and siliciclastic rocks. In total, $72 \%$ sources hold water rights, $6 \%$ mining rights, $2 \%$ geothermal rights and $1 \%$ has no rights. The permits allow much higher water abstraction as currently listed. Usage for bathing and balneology encompasses $24 \%$ of all active sources (155), some of these also with heating (23). 104 objects (16\%) are used for heating, also district heating (13) and individual space heating (3). An additional 10\% (70) are used in agriculture, mainly greenhouse heating. There are 41 reinjection wells $(5 \%)$. It is primarily in Hungary that drinking water (17\%), industrial usage (5\%) and monitoring wells (2\%) are also common.
\end{abstract}

Keywords Direct use $\cdot$ Water temperature $\cdot$ Transboundary aquifer $\cdot$ Thermal water $\cdot$ Exploitation

This article is a part of the Topical Collection in Environmental Earth Sciences on "Mineral and Thermal Waters" guest edited by Drs. Adam Porowski, Nina Rman and Istvan Forizs, with James LaMoreaux as the Editor-in-Chief.

\section{Nina Rman}

nina.rman@geo-zs.si

1 Geological Survey of Slovenia, Dimičeva ul. 14, 1000 Ljubljana, Slovenia

2 Ministry of Regional Development and EU Funds, Miramarska cesta 22, 10000 Zagreb, Croatia

3 Geological Survey of Croatia, Milana Sachsa 2, 10000 Zagreb, Croatia

4 Mining and Geological Survey of Hungary, Columbus 17-23, Budapest 1145, Hungary

\section{Introduction}

Pannonian sedimentary basin has a huge geothermal potential for direct use of thermal water (Horváth et al. 2015; Nádor et al. 2012; Rman et al. 2015a; Tóth et al. 2016, and many others) but with still prevalent use for bathing and balneology. In this region, many of these vast geothermal resources have been used for a long time: not only mainly

5 Geological Institute of Romania, 1 Caransebes St., Sector 1, 012271 Bucharest, Romania

6 Geological Survey of the Republic of Srpska, Vuka Karadžića 148b, 75400 Zvornik, Bosnia and Herzegovina

7 Faculty of Mining and Geology, Belgrade University, Djusina 7, Belgrade 11 000, Serbia

8 Federal Institute for Geology-Sarajevo, Ustanička 11., 71210 Ilidža, Bosnia and Herzegovina

9 Gradbeni inštitut ZRMK d.o.o., PE Maribor, Jezdarska ulica 2, 2000 Maribor, Slovenia 
for bathing and balneology, but also to some extent in the agricultural sector, and for space heating. This indicates that despite the large number of geothermal sources in the region, their efficient use for increased heat production which would fit the actual potential still needs many efforts.

Quantification of worldwide use of geothermal energy is prepared every 5 years at the World Geothermal Congress (Lund et al. 2015) and provides a solid base for evaluation of geothermal market evolution over time. It is performed also in countries along the southern rim of the Pannonian basin, presented in this paper, in Bosnia and Herzegovina, Croatia, Hungary, Romania, Serbia and Slovenia. Still, this summary approach does not account for reservoir properties or distinguishes among their potentials (Rman et al. 2015a); therefore, it is not sufficient when preparing strategies for their enhanced exploitation. Several regional, national or international projects provided firm geoscientific grounds for parts of this region, for example, T-JAM (Nádor et al. 2012) and TRANSENERGY (Rman et al. 2015a; Tóth et al. 2016). The latest one, project DARLINGe, supported a detailed quantification of the current situation as presented in this paper.

Many aquifers are shared by these neighboring countries but no common management of geothermal resources is yet established (Rman et al. 2011; Tóth et al. 2016); even though, bilateral water commissions meet annually and proposal of delineation of the Upper Pannonian transboundary thermal groundwater body (TTGWB; Tóth et al. 2016) was submitted to TWAP some years ago. The Convention on the Protection and Use of Transboundary Watercourses and International Lakes (UNECE 2013), the Danube River Protection Convention (DRPC) (ICPDR 2010), and the EU Water Framework Directive (WFD) (EC 2000) provide sufficient legislative framework for its implementation.

Transboundary approach is also applied in six countries within the presented research. We jointly identified regions, reservoirs and sources with proven high geothermal potential (being able to produce thermal water with minimum outflow temperature of $30{ }^{\circ} \mathrm{C}$ ) which may help to reduce the geological risk for new investments. We assessed various utilization practices between countries and reservoirs, which may reduce operational issues for new investments. We evaluated discrepancy among actual and licensed production rates to assess environmental and legislative risks for new investments.

\section{Settings}

The investigated area extends over $99,347 \mathrm{~km}^{2}$ in six countries, north Bosnia and Herzegovina (12\%), north Croatia (28\%), south Hungary (23\%), west Romania (8\%), north Serbia (24\%) and east Slovenia (5\%) (Fig. 1). Increased heat flux of the Pannonian basin is related to thin Earth's lithosphere, since the Early-Middle Miocene (Horváth et al. 2015). Mean heat flow density is $90-100 \mathrm{~mW} / \mathrm{m}^{2}$, while geothermal gradient of about $45^{\circ} \mathrm{C} / \mathrm{km}$ (Dövenyi and Horváth 1988). The Tertiary Lake Pannon was gradually filled up by alluvial sediments being transported from the surrounding uplifting Alps and Carpathians. The severalthousand-meters-thick deposits of the Upper Miocene to Pliocene siliciclastic sediments have low thermal conductivity but quite high permeability, thus representing the main transboundary geothermal aquifers (Nádor et al. 2012; Szốcs et al. 2013; Rman et al. 2015a; Rotár-Szalkai et al. 2017), referred to as the basin fill sediments in this paper. Below-positioned Pannonian delta slope sandstones are also accounted for within this unit. In total, the 100-300-m-thick sandy intercalations among fine-grained sediments occur at depths to about $2 \mathrm{~km}$ in the deepest parts of the basin, where the temperature reaches up to $90{ }^{\circ} \mathrm{C}$.

The second main type of geothermal reservoirs is the karstified Paleozoic-Mesozoic carbonates and fractured zones of the crystalline rocks in the basement of the sedimentary basin. They are characterized by high secondary porosity where the reservoir temperature can exceed $100-120^{\circ} \mathrm{C}$ due to greater depths (Goldscheider et al. 2010). Some minor fissured Miocene sandstone and carbonate geothermal aquifers capping the basements highs are also known. All these are referred to as basement rocks in this paper.

\section{Methodology}

Over 50 parameters were collected per each geothermal source, which is either a natural phenomenon-a thermal spring, or a man-made source-a geothermal well. The selection criteria were:

- Geothermal sources must be able to produce thermal waters of $30^{\circ} \mathrm{C}$ and above. Data collection in Hungary and Serbia was also carried out for wells with the present outflow temperatures lower than $30^{\circ} \mathrm{C}$, but which reached the temperature of $30^{\circ} \mathrm{C}$ or above at the time of drilling.

- Geothermal sources must have an active production or reinjection of thermal water. This overview also included active wells which do not yet hold an exploitation permit.

- Inactive wells were included in two cases: if they had been granted an exploitation permit or if they belong to a national monitoring network for geothermal aquifers.

The reference year for which data was collected was mostly 2015, as in most countries at least 1 year is needed 


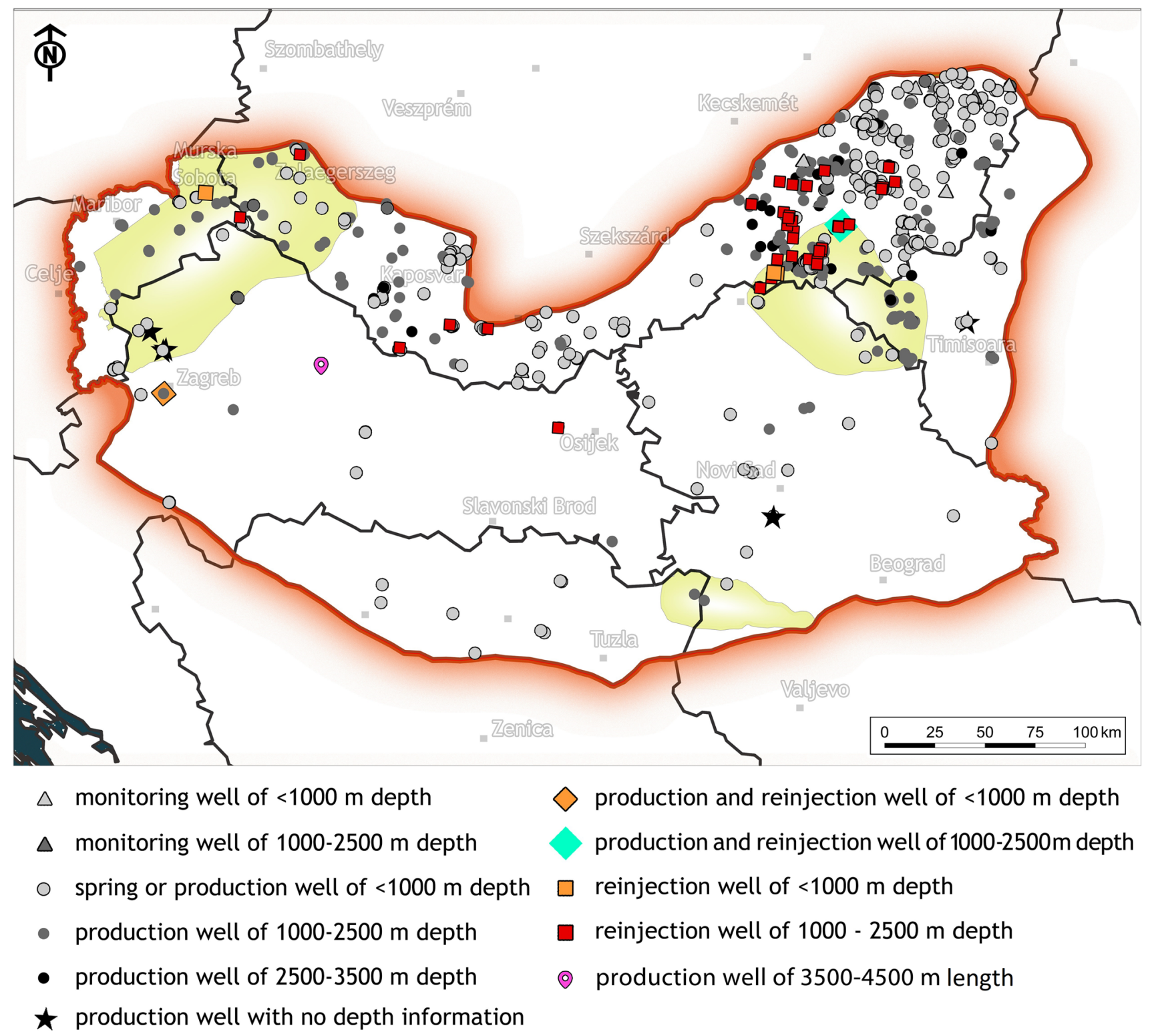

Fig. 1 Distribution of 771 geothermal sources in the investigated area (red shaded line is the boundary of the DARLINGe project area). Wells are classified by operational (open) depths or lengths and drilling purpose (production, reinjecton or monitoring well)

to update the national databases (if they exist). However, in some countries, more recent data were available.

In the Federation of Bosnia and Herzegovina, the data on currently exploited amounts of thermal water refer to the year 2015, except for one well where the amount given is an estimation. The data on the licensed maximum annual production $\left(\mathrm{m}^{3} /\right.$ year and $\left.1 / \mathrm{s}\right)$ relate to $\mathrm{A}+\mathrm{B}$ reserves, which were verified (licensed) in different years (between 2014 and 2017).

In Croatia, most of the data collected refer to the year 2015, while some data (such as the type of utilization, the existence of a cascade system, etc.) were collected through interviews conducted in 2017, and information on geothermal electricity plant in Velika Ciglena was added in 2019.

In Hungary, about $90 \%$ of the data refer to 2015, while the data on a total of 66 wells (about 10\%) refer to 2016 and 2017. In this latter case, data were provided by the regional Water Directorates and by individual users.

In Romania, most recent geothermal documentation was compiled at an authority, but since the information on the flow rate, licensed annual production and reinjection quantity and discharge is confidential, it was, therefore, not provided. 
In Serbia, the data collected vary due to limited access, accompanied by a low users' response rate. Most of the data (80\%) refer to the $2014 / 2015$ period. Exploitation concessions were granted for the period from 2011 to 2016 (the validity of concessions is 5 years and reissuing is required upon their expiry), which means some of the data collected refer to the 2012/2013 period.

In Slovenia, most thermal water users were granted water concessions at the end of 2015, and therefore, reliable monitoring data had existed since 2016 and were used in the overview. The data include source activity, outflow temperature and wastewater temperature, type of utilization permit and licensed quantities reported as valid in 2017.

\section{Data harvesting and availability}

The data were collected from various databases, mostly by contacting either the management authorities or the users themselves. The parameters for which $90 \%$ and more data were available in total are assumed to provide a solid basis for the overview. As Hungary has $79 \%$ of all sources included in the investigation, weighting had to be done to show more relevant availability of information.

If "'no information", was reported, it counted as if no data were available. Where $75 \%$ and less data were available, precautions had to be taken for its interpretation and further use, due to the possibility of this data being strongly biased either by country or another factor.

The availability of the source names, locations, reservoir type (but not yet temperature), user name, depth, year of completion, type, purpose, outflow temperature and maximum discharge was almost complete. However, the information on the activity of sources and related production and reinjection quantity, thermal water use (by cooling of mixing prior to use), and wastewater temperature is rather sparse. What is surprising is that, for the most part, the information on licensed/granted amounts of thermal water is not easily available, except for Slovenia.

Some modifications of the data gathered were needed prior to interpreting the results. For example, if the operational well depth was unknown, the quantity was assumed to be identical to well depth. The year of completion was assigned the number 0 for thermal springs to be distinguishable in the course of the statistical analysis, and so were the well depth and operational depth (if not stated differently for some captured springs). Last but not least, the temperature of three wells in Hungary and one well in Serbia has decreased from the $30-35{ }^{\circ} \mathrm{C}$ at the time of drilling to below $30{ }^{\circ} \mathrm{C}$ nowadays; so they were still included in the analysis. The data were interpreted using MS Office Excel and ArcGIS Map.

In the Federation of Bosnia and Herzegovina (BA), the data were taken from the Cadastre and GIS database of mineral, thermal and thermomineral waters of BA, which are maintained and continuously updated by the Federal Institute of Geology, from the Federal Ministry of Energy, Industry and Mining, which assesses and monitors the reserves of these waters, from the Sava River Watershed Agency Sarajevo, and from the users as well. All users were also interviewed. In the Republic of Srpska, the data are mostly based on the documents stored in the Central Geological Archive, which is kept by the Geological Survey of the Republic of Srpska. The data on current exploitation refer to the year 2015 except for one spring where an estimation was made in 2017. The data on the licensed maximum annual production are taken from reports on the reserves which represent an obligatory part of the application for a concession permit. The term "Mining Right" stands for the exploitation license obtained from the Federal Ministry of Energy, Mining and Industry based on the Law on Geological Investigation, and the term "Water Right" means a valid Concession Agreement. Concessions (water rights) are issued by cantons (10 cantons in the Federation of Bosnia and Herzegovina, three of which are included in the project area) and different ministries in the cantons; in some cases, it is the Government of the Federation of Bosnia and Herzegovina that issues concessions, and it is, therefore, difficult to tell which institutions can provide information on concessions. The decisions on concessions are public and are published in the Official Gazettes of respective cantons or the Federation of Bosnia and Herzegovina. Official Gazettes of cantons are not available via the internet, which makes them very difficult to access, and we could, therefore, not collect the information on the concessions for some wells.

In Croatia (HR), no unified database exists. The Ministry of Environment and Energy keeps a concessions database which is not accessible to the public and is divided among two departments into two sub-databases: concessions under the Hydrocarbon exploration and exploitation Act (if thermal waters are used for the purposes of energy production) and water permits (called concessions until 2017) under the Water Act (if thermal waters are used for balneology purposes; some spas are using them for heating). Only $70 \%$ of the users responded to our investigation and even those often gave partial information as they do not systematically collect all such data. By law, it is obligatory only to monitor the amount of water produced and, periodically, the wastewater temperature. Croatia reported 'Mining/Water Right in Progress" as a type of utilization permit, which was accounted for as if the right had already been granted. In Croatia, the information on the granted amounts of thermal water is not available to the public. The only public information available is whether or not a user holds a permit, and if so, the permit number, date of issuing and date of expiry.

In Hungary, the data were taken from the central database of the Mining and Geological Survey of Hungary (MBFSZ), 
while additional data were provided by the regional Water Directorates and by individual users. Unfortunately, not all users responded to our survey. Here, the licenses on geothermal wells are not open to the public, and neither is their data. The regional Water Directorates should have this information, but since the granting of water rights (except below $2500 \mathrm{~m}$, which is subject to mining concession under the competence of the Mining and Geological Survey of Hungary), is done by the regional Directorates for Disaster Management, these data are available by default. Due to a high number of geothermal sources in Hungary and the timeframe available, it was not possible to collect the data from this source.

In Romania, a representative of the Romanian ASP, National Agency for Mineral Resources, provided information on 55 wells from their recent geothermal documentation. The information on the flow rate, licensed annual production and reinjection quantity and discharge is still confidential, and is, therefore, not provided. The coordinates of the source are part of the license and are published in the Official Monitor. The data published on the website of the National Agency for Mineral Resources contain only the following: the substance, license owner, and their contact data (address and phone number). It may happen that exploitation licenses are not listed (excepting "waiting for approval"). This is why, at present, in Arad and Timis countries, there are no exploitation licenses for geothermal water. However, once an approval is obtained from the National Agency for Mineral Resources, a company is allowed to extract geothermal water, but needs to provide an annual a report on the water extracted. During this time, the company attempts to obtain the other necessary approvals from the Local Environmental Agency, Ministry of Culture, and Romanian Waters Authority. It is only after these approvals have been obtained that the license is published in the Official Monitor. The amount of geothermal water produced is not confidential, nor is it publicly available online. It must be obtained from the National Agency for Mineral Resources or directly from the well owner.

In Serbia (RS), there is no centralized database; so the data were collected from several available sources, including personal contacts with the users. For the territory of the Autonomous Province of Vojvodina, which covers almost the $90 \%$ of the project area in Serbia, the Provincial Secretariat for Energy, Construction and Transport is running a geothermal database on exploitation and exploration licenses. This database is partly open to public. The Ministry for Mining and Energy is authorized for the rest of the territory of Serbia. A similar database is run under this governmental body. The license on groundwater/geothermal use is publicly available through two web applications. Depending on the territorial jurisdiction, Provincial Secretariat for Energy, Construction and Transport is running a database covering the territory of Vojvodina; while the rest of Serbia is under the competence of the Ministry of Mining and Energy. These databases provide information on the name of the user, the type of mineral source (groundwater/ thermal water), location, license number and date of issuing. Data preview is organized both graphically and textually. Every licensed user is obliged to provide an annual report on monitoring the data (yield and temperature). These data are not publicly available, nor are the characteristics, chemical composition and hydraulic data of the source. The database is periodically updated.

In Slovenia, the Geological Survey of Slovenia runs the most detailed national geothermal exploitation database as it annually interviews users on their utilization practice (water temperatures, quantities and type of use), within which they voluntarily participate. However, since 2015 , all users with granted water permits annually report monitoring results to the Environmental Agency; thus, the reliability of exploitation data has much improved. The exploitation rights may be issued by two laws. The Ministry of the Environment and Spatial planning manages the granting procedure for the Water concession, while the Ministry of Infrastructure for the Mining concession, the latter is issued only for doublets. Both publish the Decrees on Water and Mining Concessions in the Official Gazette of the Republic of Slovenia (also on the web), providing a freely accessible document with basic information on the sources. Public databases elaborated within the previous EU projects T-JAM and TRANSENERGY were also used.

\section{Results and discussion}

\section{Identified geothermal sources}

According to the set criteria, a total of 771 geothermal sources were identified in the six countries (Table 1). Their highest density was recorded in Hungary, followed by Slovenia and Romania, while Serbia, Croatia and Bosnia and Hercegovina have much less geothermal sources. While the drilling purposes of sources are well known, the information on their activity is much poorer. Monitoring wells were reported only in Croatia (1) and Hungary (12). There is a total of 714 production wells and springs, of which there are 128 with a continuous production, 76 with a periodical (mostly seasonal) and 5 with occasional (random) production; no information was available for 403 wells, whilst 102 are known to be inactive. Only one production-reinjection well is reported in Croatia (the Mla-2 reinjection well of $911 \mathrm{~m}$ cased in carbonates) and one that is $2.2-\mathrm{km}$ deep in Hódmezóvásárhely in Hungary. The reinjection part of the Hungarian well was in operation only for a short time, and at present only its production part operates. The Mla-2 well 


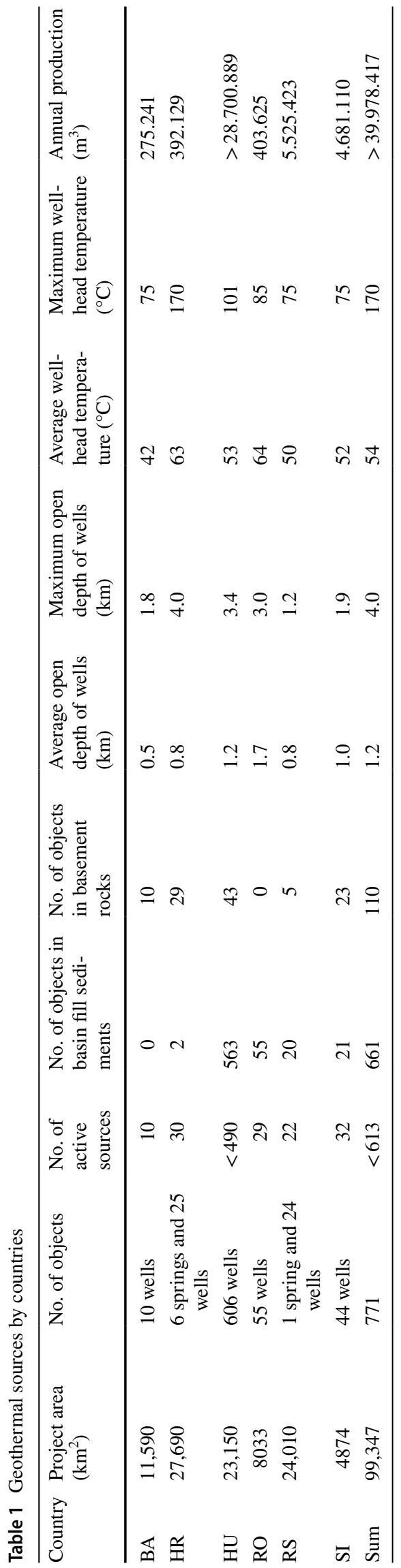

in Croatia was drilled in 1985 because the Mla-1 did not produce water at sufficient temperatures. It was planned to be a production well and because of good testing results, an additional Mla- 3 well was drilled $2 \mathrm{~m}$ away from Mla-2. In Mla-2, lithothamnium limestones of Prečec Formation have been tapped at $883-911 \mathrm{~m}$, and the well produces water of $63-65^{\circ} \mathrm{C}$. The static pressure at the wellhead is 7.8 bar. The optimal yield is $25 \mathrm{l} / \mathrm{s}$ at a temperature of $63{ }^{\circ} \mathrm{C}$. Nowadays, Mla-2 is used as a reinjection well because it has a lower temperature and a lower static/dynamic pressure than the Mla-3 with water of $78-80{ }^{\circ} \mathrm{C}$. In case of a higher water demand, Mla- 2 can be used as a production well and Mla-1 would probably become a reinjection well.

As many as 39 wells are listed to be drilled for reinjection, 5 of them are constantly, 4 periodically and 14 at least occasionally active, while no information on the frequency of activity is available for the remaining 16 . More specifically, one well is active in Bizovac, one in Zagreb in Croatia, the third one in Lendava in Slovenia; while the one in Moravske Toplice is now used for production instead of reinjection. At least, 18 active reinjection wells exist in Hungary, while no information on current activity was available for the others. Therefore, good practice on reinjection can be described for porous and carbonate aquifers. There is one well in Hungary which produces water and is reinjected into a fractured crystalline formation near a tectonic zone (Szentlórinc), while the rest operate in porous and karstic aquifers. There is no reinjection occurring in the Romanian, Bosnian and Serbian parts of the project area.

Based on the reported operational depths of 744 sources, we can conclude that the average depth is approximately $1145 \mathrm{~m}$, while the maximum depth is $3436 \mathrm{~m}$ (Fig. 1). When comparing the average operational depths between the countries, it can be seen that the depth decreases from $1.8 \mathrm{~km}$ in Romania to $1.2 \mathrm{~km}$ in Hungary, $1.0 \mathrm{~km}$ in Slovenia, $0.9 \mathrm{~km}$ in Serbia, and $0.5 \mathrm{~km}$ in Croatia and Bosnia and Hercegovina. This is partly geology dependent. We plan to compare these numbers against the depth parameter of the Pannonian Basin when the reservoir delineation is finished.

The year of completion of the wells was reported for 735 sources (Fig. 2). As for individual countries, the years of completion range from 1957 to 2013 for Bosnia and Hercegovina, from 1960 to 2010 for Croatia, from 1901 to 2016 for Hungary, from 1900 to 2008 for Romania, from 1974 to 2015 for Serbia and from 1949 to 2011 for Slovenia. Individual percentages show that $13 \%$ of wells are younger than 10 years, $8 \%$ are $10-20$ years old, $9 \%$ are $20-30$ years old, $22 \%$ are $30-40$ years old, $22 \%$ are $40-50$ years old, $20 \%$ are $50-60$ years old and 6\% are over 60 years old.

The lifespan of geothermal wells is usually about 30 years and only about $29 \%$ of the wells are younger than this. This might indicate several things. On the one hand, a point in favor is that the sources obviously have a very long lifespan, 


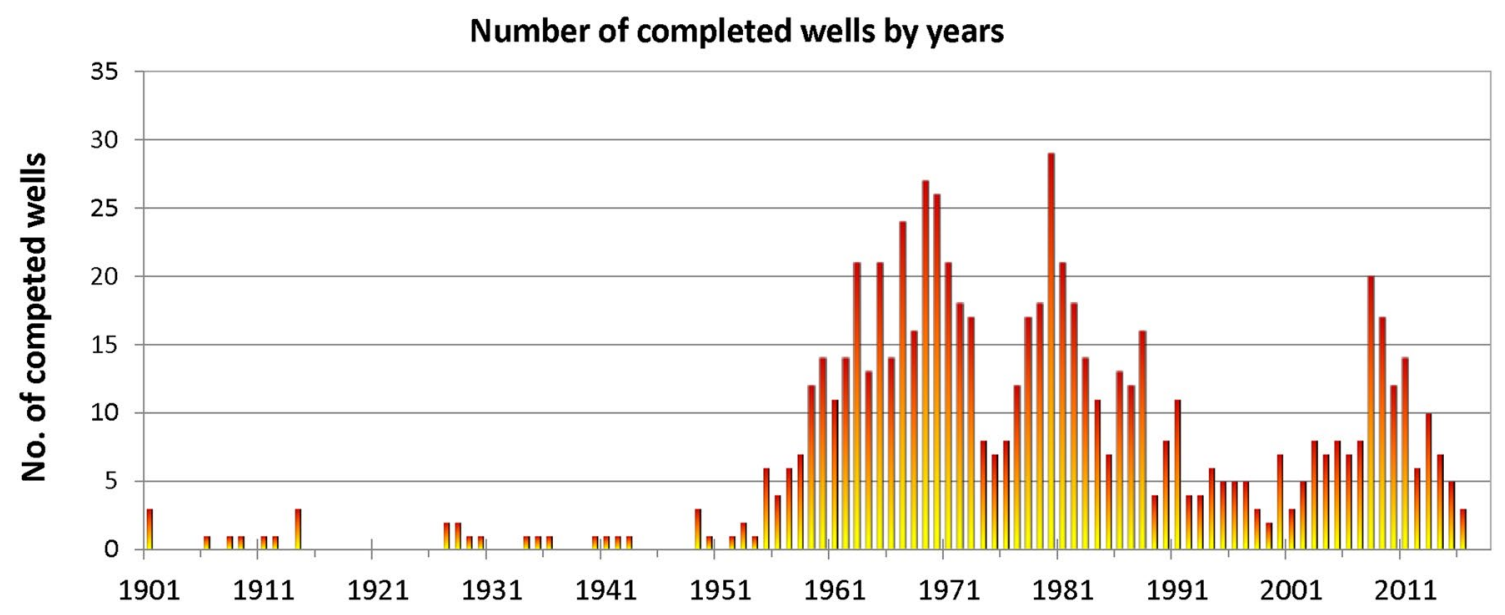

Fig. 2 Distribution of newly completed wells by years in the period 1901-2016

which makes the substantial capital investments needed for drilling and making them operational acceptable; while on the other hand, at least some of the wells may be approaching their final stages of operation due to a questionable status of the iron casing, weak cementation and plugging, and similar effects resulting from poor maintenance. The number of new wells put in operation has been decreasing in the region since 2008, which calls for new support from investors and for the maintenance of the existing ones. These facts indicate that it will be necessary to promote new investments into geothermal wells to retain the total capacity in the region in the long run.

\section{Thermal water temperature}

The average outflow temperature shows that $36 \%$ of the sources have temperatures below $40{ }^{\circ} \mathrm{C}$; while $50 \%$ of the sources have temperatures below $50{ }^{\circ} \mathrm{C}$ (Figs. 3, 4). This means that half of the listed sources are more than favorable for geothermal heat production. The temperature range is $30-75^{\circ} \mathrm{C}$ in Bosnia and Hercegovina, 32-170 ${ }^{\circ} \mathrm{C}$ in Croatia, $25{ }^{\circ} \mathrm{C}$ (originally $30{ }^{\circ} \mathrm{C}$ ) $-101{ }^{\circ} \mathrm{C}$ in Hungary, $29-85{ }^{\circ} \mathrm{C}$ in Romania, $25^{\circ} \mathrm{C}$ (originally $31^{\circ} \mathrm{C}$ ) $-75^{\circ} \mathrm{C}$ in Serbia, and $30-75^{\circ} \mathrm{C}$ in Slovenia. The highest temperatures of above $80{ }^{\circ} \mathrm{C}$ are mostly reported in Hungary, and to a lesser extent in Croatia and Romania.

\section{Drilling purposes and utilization types}

Utilization was reported per country with varied precision (Fig. 5). Unknown use was reported for a total of 130 sources in Hungary, Romania and Slovenia. To give a rational overview, some categories were joined for interpretation:
- $24 \%$ (155) are used for balneological purposes and 28 more are used for bathing and heating besides (which includes 14 cases of sanitary water heating and 21 cases of individual space heating),

- $17 \%$ (130) are used for drinking water supply primarily in Hungary,

- $16 \%$ (122) are used for different types of heating (excluding agriculture), of which $13 \%$ are used for supplying the water for district heating and $3 \%$ for individual space heating,

- $10 \%$ (70) are used for agricultural purposes mostly heating, which usually means greenhouse heating,

- $8 \%$ (58) are used for other unspecified purposes,

- $5 \%$ (41) are reinjection wells, two of them used in the electricity production system,

- $5 \%$ (36) are industrial wells,

- $2 \%$ (11) operate as monitoring wells, and

- 2 wells have been used for geothermal electricity production since the end of 2018 in Croatia.

No thermal wells are used for irrigation in BA, HR, HU, $\mathrm{RO}$ and in SI project area, and probably in Serbia.

The porous basin-fill reservoirs vastly predominate over the fissured ones, as almost six-times more sources produce thermal water from them (Fig. 6).

\section{Thermal water production, types of permits and licenced quantities}

The information on the production of sources was only available for $62 \%$ of the sources. The total annual production amounted to $5.525 \times 10^{6} \mathrm{~m}^{3}$ in Serbia $(100 \%$ data available; $76 \%$ from basin-fill and Pannonian reservoirs), $28.701 \times 10^{6} \mathrm{~m}^{3}$ in Hungary (54\% data available; $91 \%$ from basin-fill and Pannonian reservoirs), $4.681 \times 10^{6} \mathrm{~m}^{3}$ 


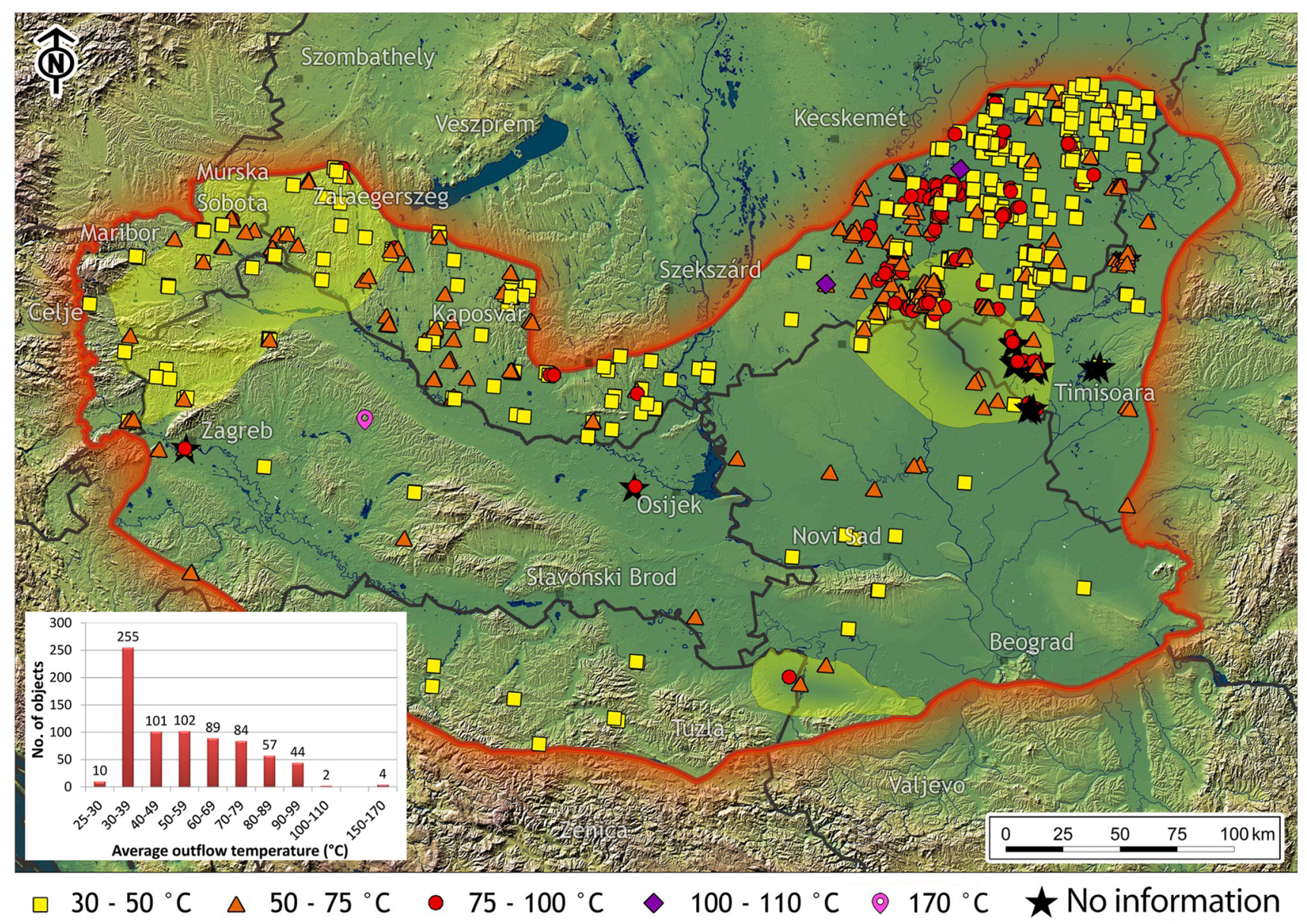

Fig. 3 Average thermal water outflow temperatures at 771 sources are classified in several categories on a topographical map of the DARLINGe project area (red shaded line). Chart in its lower left angle indicates a fast decrease of the number of sources with increasing temperatures, with the most abundant class between 30 and $39{ }^{\circ} \mathrm{C}$. The wells whose outflow temperature has decreased below $30{ }^{\circ} \mathrm{C}$ since the start of production are shown in the category $30-50{ }^{\circ} \mathrm{C}$ on the topographic map but as a separate class of $25-30{ }^{\circ} \mathrm{C}$ at the chart in Slovenia (100\% data available; $70 \%$ from basin-fill and Pannonian reservoirs), $0.392 \times 10^{6} \mathrm{~m}^{3}$ in Croatia (19\% data available; $55 \%$ from basement, Badenian and/or Sarmatian reservoirs), $0.275 \times 10^{6} \mathrm{~m}^{3}$ in Bosnia and Hercegovina (30\% data available, all from basement, Badenian and/or Sarmatian reservoirs), and $0.403 \times 10^{6} \mathrm{~m}^{3}$ in Romania (29\% data available; all from Pannonian reservoirs). In total, more than $40.0 \times 10^{6} \mathrm{~m}^{3}$ was produced in 2015 , with $85 \%$ of the thermal water produced by basin-fill (Pannonian) reservoirs and the rest by basement, Badenian and/or Sarmatian reservoirs.

The licensed maximum annual production amounts to at least $62.3 \times 10^{6} \mathrm{~m}^{3}$ per year ( $51 \%$ of available data), to $3.636 \times 10^{6} \mathrm{~m}^{3}$ per year in BA, $8.490 \times 10^{6} \mathrm{~m}^{3}$ per year in HR, $38.127 \times 10^{6} \mathrm{~m}^{3}$ per year in HU, $6.393 \times 10^{6} \mathrm{~m}^{3}$ per year in Serbia and $5.726 \times 10^{6} \mathrm{~m}^{3}$ per year in Slovenia, while no data are available for Romania. If comparing the reservoir types, a total of $18.7 \times 10^{6} \mathrm{~m}^{3}$ per year $(30 \%)$ plans to be extracted from basement, Badenian and Sarmatian reservoirs, with the other $43.7 \times 10^{6} \mathrm{~m}^{3}$ per year $(70 \%)$ from the porous basin-fill (Pannonian) reservoirs. No precise data are available for the licensed reinjection quantity, except for a well in Slovenia with a granted amount of $1 \times 10^{6} \mathrm{~m}^{3}$ per year for reinjection.

Capacity of thermal water wells is tested by long-term pumping tests in all six countries. These result in threshold values-critical points, which stand for the maximum pumping rate and the drawdown per a well which enable a new quasy-steady state. Therewith, characteristic physicochemical properties of thermal water are constant and no operational problems occur (e.g., no silt discharges, etc.).

Regarding the granted permits, water rights prevail in Croatia, Hungary, and Slovenia, geothermal rights in Serbia, and mining rights in Bosnia and Hercegovina and Romania. In total, $72 \%$ wells have had granted water rights (556), $18 \%$ have no information on permits (137), $6 \%$ have mining rights (47), $2 \%$ geothermal rights (16), and $1 \%$ have no rights granted (11). 


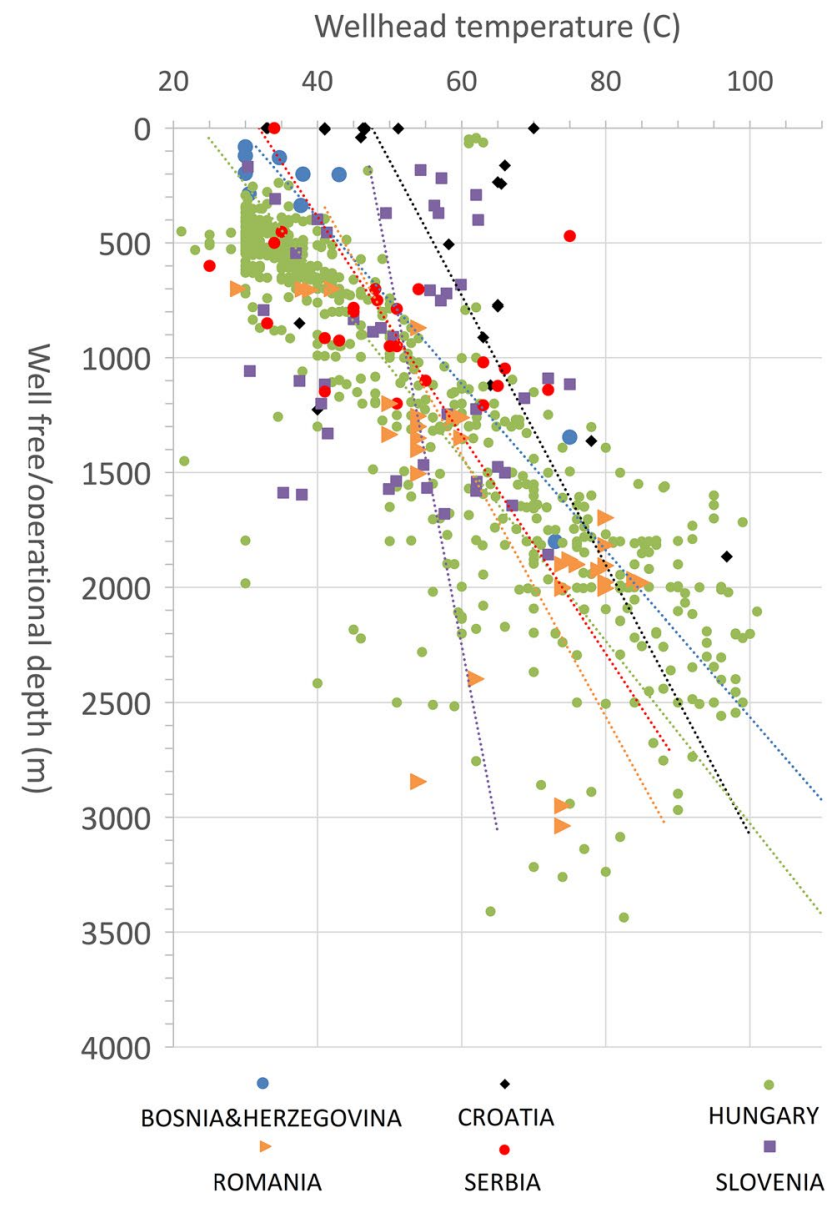

Fig. 4 Geothermal gradients in the six countries can be roughly assessed from the distribution of average outflow temperatures of the 771 geothermal sources with their operational (open) depth. Springs are drawn at $0 \mathrm{~m}$

In Croatia, thermal water utilization is regulated by two different laws, depending on the purpose of utilization. If the purpose is to use water (bottling, swimming, balneology), then the Water Law is amenable (Official Gazette 153/09, $63 / 11,130 / 11,56 / 13,14 / 14)$. On the other hand, the Hydrocarbon exploration and exploitation Law is amenable (Official Gazette 52/18, 52/19) if the purpose is to use the energy (heating, electricity generation). Since swimming and balneology utilization prevail, there are more water permits than mining permits (concessions) in Croatia.

In Hungary, the type of utilization was reported only if an exact answer to the distributed questionnaire was received; however, all operating wells should have a license. Water rights were assigned to those which have a license confirmed in the questionnaire. A water right can also be assumed for others with no information, as it was compulsory to obtain the license by now; therefore, the wells which report their water production to authorities or operate as monitoring wells most probably also have a license.
In Romania, geothermal, mineral groundwater, as well as therapeutic water, is considered as a subsoil resource and is administered by the National Agency for Mineral Resources. Surface waters and groundwater resources, as well as the infrastructure for their exploitation, are administered by the Romanian Waters Authority (Apele Romane).

In Slovenia, thermal water use without $100 \%$ reinjection is governed by the Water Law and concessions for spa/ balneology, and spa/balneology and heating are granted as water permits. Only one mining concession is granted for a production-reinjection pair of wells in Lendava with a demanded $100 \%$ reinjection.

\section{Conclusions}

This research confirms the huge geothermal heat potential of the southern part of the Pannonian basin. A total of 771 geothermal objects were examined, where the majority are involved with thermal water production and only about $5 \%$ are reinjection wells. The average well depth of approximately $1145 \mathrm{~m}$ is still reasonable for developing economically durable heating projects, especially if two facts are considered. The first is that most of the wells have been operating successfully for several decades, while the second appertains to the high thermal water outflow temperatures; these exceed $50{ }^{\circ} \mathrm{C}$ at half of the identified sources, the highest one reaching $170{ }^{\circ} \mathrm{C}$ in Croatia and being used for electricity production. Among geothermal aquifers, the porous basin fill sediments significantly predominate. They are tapped by six times more wells than the fractured, karstified basement rocks, giving them a very high share (85\%) of the total production. Usage for bathing and balneological purposes is still prevalent with respect to $24 \%$ of all sources, while the share of various heating systems represents about $30 \%$.

One may wonder why this article does not quantify the geothermal potential from three aspects (Rman et al. 2015a): potential of inactive wells, legislative and energy potentials as some of these data have tried to be gathered in the survey. Additionally, the sustainability of thermal water production from the regional Pannonian basin reservoirs is of major importance when planning further geothermal development (Buday et al. 2015; Rman et al. 2015b; Szanyi and Kovács 2010). The reason is that reliable geothermal source-specific data are extremely difficult to be provided to non-agencies. Granted concession- and actual production rates as well as results of environmental impact monitorings are most often confidential in all six investigated countries. Therefore, any quantification made from the available data sets would be subjected to high uncertainties and was rather not made.

The highlighted rich experience in the Pannonian basin indicates that a significant increase in geothermal heat 


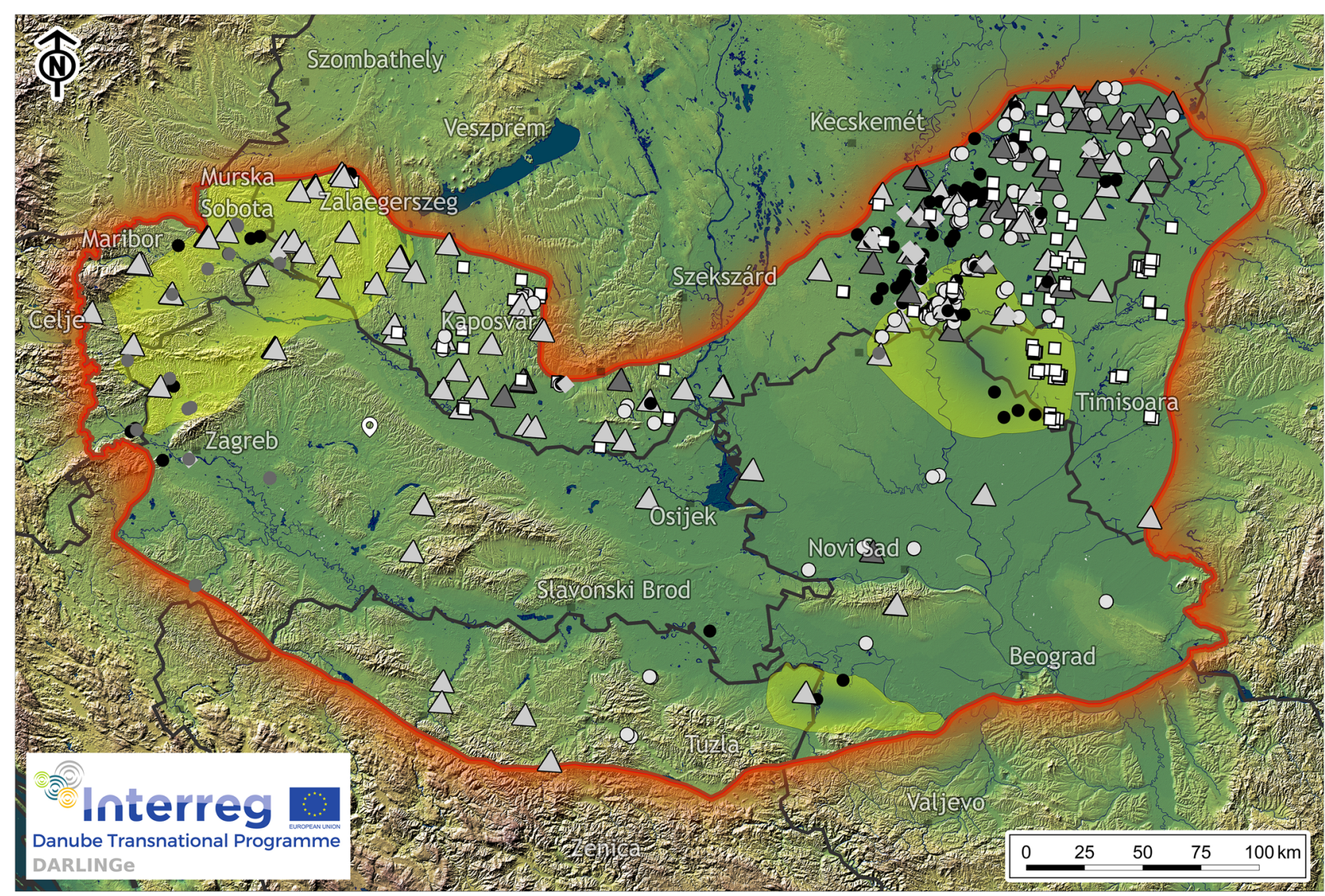

\section{$\triangle$ balneology/spa}

- balneology/spa and heating

- $\quad$ heating (not specified)

$\triangle \quad$ agriculture (not specified) other use

$\checkmark$ reinjection well

no information

(-) geothermal electricity
Fig. 5 Generalised types of utilization for 672 springs and wells. Heating includes district heating, sanitary water heating and individual space heating. Agriculture includes different agricultural uses,

production can be achieved in near future if sufficient investment support is available, among others. We propose sequential approach. First, the energy efficiency at existing geothermal sources should be enhanced by applying higher thermal efficiency to the existing or lower-than-current thermal water flow rates. Secondly, if granted production rates are not being exploited in a time period (e.g., a well is inactive for 5 years, for example), the quantity should be also heating of greenhouses. Other use stands mostly for industrial use and monitoring wells. Red shaded line is the boundary of the DARLINGe project area

transferable to another user to enable for further development. Thirdly, at transboundary areas and regions with multiple users in the same geothermal aquifer, or where risks of thermal and chemical pollution of surface waters are identified as well as risks for deterioration of aquifers' state, new reinjection wells should be implemented to retain sufficient recovery and longevity of the reservoir. 


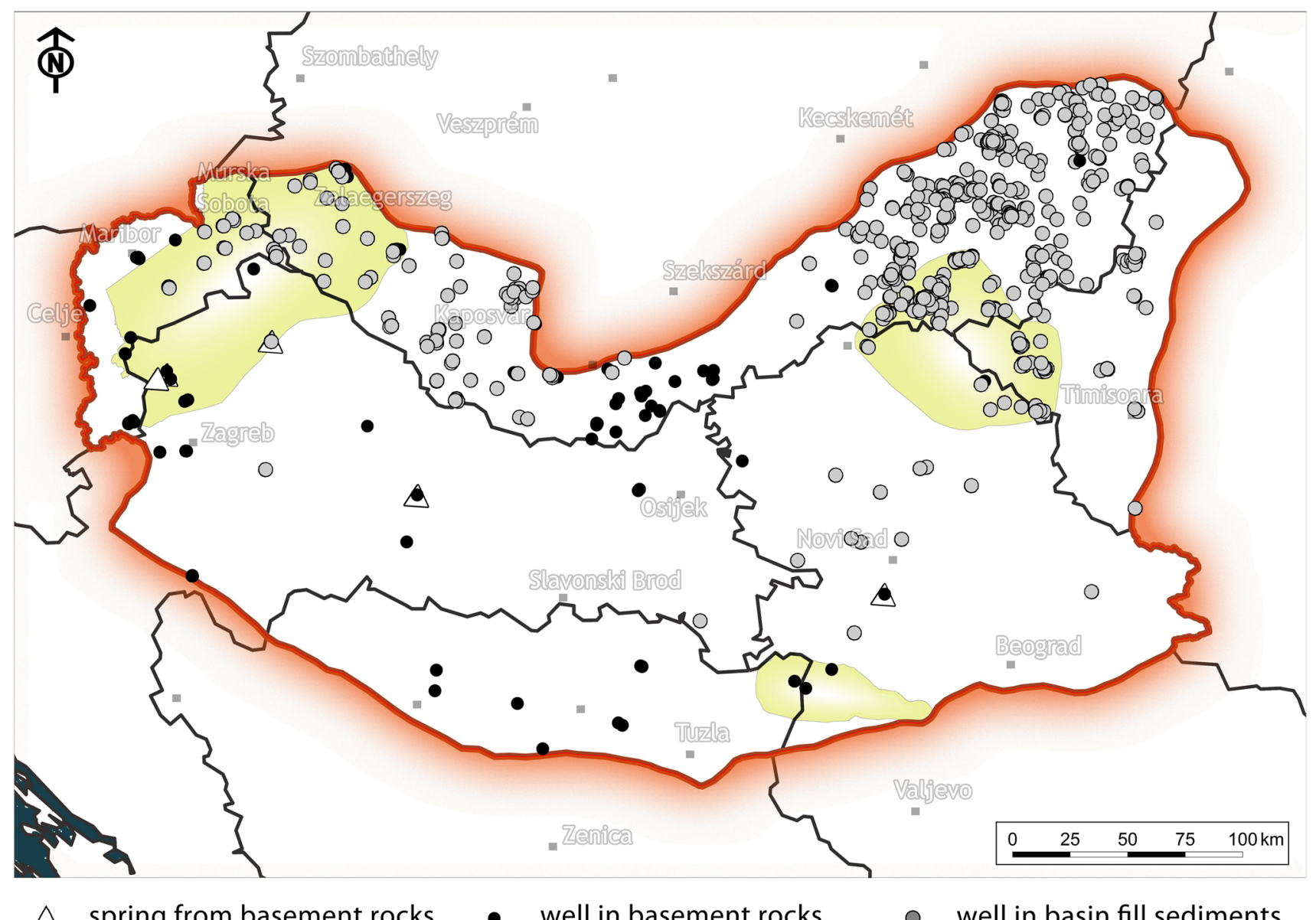

Fig. 6 Spatial distribution of 7 springs and 764 geothermal wells which predominately tap two different geothermal reservoirs, either porous Pannonian basin fill sediments of fissured basement rocks. Red shaded line is the boundary of the DARLINGe project area

Acknowledgements Datasets and reports are available at http://www. interreg-danube.eu/approved-projects/darlinge/ and the portal www. darlinge.eu. Research within the DARLINGe project was supported by the European Regional Development Fund and by the Instrument for Pre-Accession Assistance II under Grant Agreement No. DTP1099-3.2. Research activities were performed also within the Slovenian ARRS Programme P1-0020 Groundwaters and Geochemistry. The authors thank to S. Mozetič for preparation of graphical material.

Open Access This article is licensed under a Creative Commons Attribution 4.0 International License, which permits use, sharing, adaptation, distribution and reproduction in any medium or format, as long as you give appropriate credit to the original author(s) and the source, provide a link to the Creative Commons licence, and indicate if changes were made. The images or other third party material in this article are included in the article's Creative Commons licence, unless indicated otherwise in a credit line to the material. If material is not included in the article's Creative Commons licence and your intended use is not permitted by statutory regulation or exceeds the permitted use, you will need to obtain permission directly from the copyright holder. To view a copy of this licence, visit http://creativecommons.org/licenses/by/4.0/.

\section{References}

Buday T, Szúcs P, Kozák M et al (2015) Sustainability aspects of thermal water production in the region of HajdúszoboszlóDebrecen, Hungary. Environ Earth Sci 74:7511-7521. https:// doi.org/10.1007/s12665-014-3983-1

Dövenyi P, Horváth F (1988) A review of temperature, thermal conductivity and heat flow data for the Pannonian Basin. In: Royden LH, Horváth F (eds) The Pannonian Basin: a study in basin evolution. 45 AAPG Memoir, Tulsa, Budapest, pp 195-233

EC (2000) Directive 2000/60/EC of the European Parliament and of the Council establishing a framework for the Community action in the field of water policy (Water Framework Directive). OJ L 327: $237 / 231-327 / 272$

Goldscheider N, Mádl-Szőnyi J, Erőss A, Schill E (2010) Review: thermal water resources in carbonate rock aquifers. Hydrogeol J 18:1303-1318. https://doi.org/10.1007/s10040-010-0611-3

Horváth F, Musitz B, Balázs A et al (2015) Evolution of the Pannonian basin and its geothermal resources. Geothermics 53:328352. https://doi.org/10.1016/j.geothermics.2014.07.009 
ICPDR (2010) Groundwater guidance. International Commision for the Protection of the Danube River. http://www.icpdr.org/main/ publications/guidance-documents. Accessed 28 Sept 2019

Lund WJ, Bertani R, Boyd TL (2015) Worldwide geothermal energy utilization 2015. GRC Trans 39:79-92

Nádor A, Lapanje A, Tóth G et al (2012) Transboundary geothermal resources of the Mura-Zala basin: joint thermal aquifer management of Slovenia and Hungary. Geologija 55(2):209-224. https ://doi.org/10.5474/geologija.2012.013

Rman N, Lapanje A, Prestor J (2011) Water concession principles for geothermal aquifers in the Mura-Zala Basin, NE Slovenia. Water Resour Manag 25(13):3277-3299. https://doi.org/10.1007/s1126 9-011-9855-5

Rman N, Gál N, Marcin D, Weilbold J, Schubert G, Lapanje A, Rajver D, Benková K, Nádor A (2015a) Potentials of transboundary thermal water resources in the western part of the Pannonian basin. Geothermics 55:88-98. https://doi.org/10.1016/j.geothermic s.2015.01.013

Rman N, Lapanje A, Prestor J et al (2015b) Mitigating depletion of a porous geothermal aquifer in the Pannonian sedimentary basin. Environ Earth Sci 75:723. https://doi.org/10.1007/s1266 5-016-5634-1

Rotár-Szalkai Á, Nádor A, Szôcs T, Maros G, Goetzl G, Zekiri F (2017) Outline and joint characterization of Transboundary geothermal reservoirs at the western part of the Pannonian basin. Geothermics 70:1-6. https://doi.org/10.1016/j.geothermics.2017.05.005

Szanyi J, Kovács B (2010) Utilization of geothermal systems in South-East Hungary. Geothermics 39(4):357-364. https://doi. org/10.1016/j.geothermics.2010.09.004

Szőcs T, Rman N, Süveges M et al (2013) The application of isotope and chemical analyses in managing transboundary groundwater resources. Appl Geochem 32:95-107. https://doi.org/10.1016/j. apgeochem.2012.10.006

Tóth G, Rman N, Rotár-Szalkai Á, Kerékgyártó T, Szőcs T, Lapanje A, Černák R, Remsík A, Schubert G, Nádor A (2016) Transboundary fresh and thermal groundwater flows in the west part of the Pannonian Basin. Renew Sustain Energy Rev 57:439-454. https ://doi.org/10.1016/j.rser.2015.12.021

UNECE (2013) Convention on the Protection and Use of Transboundary Watercourses and International Lakes (Water Convention). https://www.unece.org/env/water/text/text.html. Accessed 28 Sept 2019

Publisher's Note Springer Nature remains neutral with regard to jurisdictional claims in published maps and institutional affiliations. 